УДК 631.8:633.14-152.75:633.11 «324»

(C) 2012

Білітюк А. П., кандидат сільськогосподарських наук

Волинський інститут агропромислового виробництва

Новицька Н. В., кандидат сільськогосподарських наук,

Максимюк В. П., матістр *

Національний університет біоресурсів і природокористування України

\title{
ФОРМУВАННЯ ВРОЖАЮ ТА ЯКОСТІ ЗЕРНА ТРИТИКАЛЕ ОЗИМОГО ЗАЛЕЖНО ВІД УДОБРЕННЯ В УМОВАХ ЗАХІДНОГО ПОЛІССЯ
}

\section{Рецензент - кандидат сільськогосподарських наук В. М. Рожко}

Наведені результати досліджень норм, строків $i$ видів мінеральних добрив у технології вирощування тритикале озимого на дерново-підзолистому супішаному трунті західного Полісся Украӥни після попередника - гороху. Встановлено, щзо оптимальною нормою мінеральних добрив для формування високоякісного зерна тритикале озимого сорту Поліський 7 є $N_{120} P_{60} K_{120}$, із внесенням $N_{30}$ до сівби $+N_{30}$ на III $+N_{30}$ на V $+N_{30}$ на VII етапах органогенезу в формі карбаміду і КАС. На иьому агрофоні врожайність зерна становила 5,98-5,88 m/2а із вмістом 14,1-14,2\% білка и 21,1\% клейковини відповідно. Мінеральні добрива забезпечували високу польову схожість і продуктивну кущистість рослин, збільшували показники вмісту в зерні крохмалю, золи, фосфору $і$ калію, збільшували параметри висоти стебла та колоса прапорцевого листа, кількість колосків у колосі, зерен у ньому.

Ключові слова: тритикале озиме, добрива мінеральні, врожайність, структура, сорт, добрива, якість зерна.

Останнім часом в Україні все більше надається уваги вирощуванню тритикале, як молодої високоврожайної зернової культури, та можливостям його використання для забезпечення продовольчих потреб населення. За рекомендаціями фахівців, слід розширювати посівні площі під озимим тритикале, поскільки воно менш вибагливе до грунтів, має вищу стійкість до шкідників і хвороб, високу здатність конкурування 3 бур'янами. Тритикале вирощується переважно без використання пестицидів [3].

Аналіз основних досліджень і публікацій, у яких започатковано розв'язання проблеми. Як свідчать літературні дані, пшенично-житні амфідиплоїди поєднують у собі чимало кращих ознак і властивостей вихідних батьківських форм: високий потенціал врожаю зерна і зеленої маси, підвищені адаптивні властивості, комплексний імунітет до грибних захворювань, більший вміст білка i лізину в зерні та основних поживних речовин у зеленій масі [5]. Вміст білка в ньому 10-28 \%, лізину - 3,5-5,0, жиру - 2,4, цукру - 6-10\%. Це набагато більше, ніж у пшениці. Водночас у ньому міститься широкий набір вітамінів, а за амінокислотним складом білки мають вищу поживну цінність, ніж пшеничні [10].

На формування 1 т зерна тритикале витрачає в середньому 45 кг $\mathrm{N}, 10$ кг $\mathrm{P}_{2} \mathrm{O}_{5}$ й 38 кг $\mathrm{K}_{2} \mathrm{O}$. Основна маса поживних речовин засвоюється ним у періоди кущіння; колосіння, а також формування та наливу зерна. Для азоту й калію час їхнього поглинання майже повністю завершується під час цвітіння. До цього часу в рослинах тритикале накопичується 92-94 \% азоту й близько 99\% калію. Проте фосфор споживається рослинами тритикале протягом усього періоду вегетації, хоча основна його кількість надходить під час цвітіння, інші 20-22 \% засвоюються до фази воскової стиглості [2].

Для збільшення врожайності та валових зборів зерна тритикале важливе значення має раціональне використання органічних і мінеральних добрив. Вони позитивно впливають на зимостійкість рослин, загальне їх виживання, ріст і розвиток, фотосинтетичну діяльність, продуктивність та якість зерна. Під їх впливом у зерні збільшується вміст білку, незамінних амінокислот $[1,6]$.

Інтенсивні технології вирощування тритикале, основою яких є оптимізація рівня азотного живлення за рахунок диференційного їх внесення по етапам органогенезу, на фоні достатнього забезпечення фосфором та калієм у поєднанні 3 ретардантним захистом дають змогу суттєво (на 60-70 ц/га) збільшити продуктивність цієї культури [9].

\footnotetext{
"Керівник - кандидат сільськогосподарських наук Н. В. Новицька
} 
Оптимізація норм і строків внесення азотних добрив базується на даних рослинної та грунтової діагностики за фазами розвитку тритикале. Роздрібне внесення азотних добрив забезпечує істотні прирости врожаю зерна й суттєво впливає на вміст білка в зерні [7].

Мета і завдання досліджень - вивчення ефективності застосування різних норм і видів мінеральних добрив у посівах районованого для зони Полісся України озимого тритикале сорту Поліський 7 (селекції ННЦ «Інститут землеробства УААН») та їх вплив на врожайність і якість зерна.

Матеріали і методи досліджень. Дослідження проводили у державному дослідному господарстві «Рокині» Волинського інституту АПВ НААН України на дерново-підзолистому супіщаному грунті. Орний шар грунту (0-20 см) дослідних ділянок характеризується такими агрохімічними показниками: вміст гумусу - 1,8\%, $\mathrm{pH}$ сольової витяжки - 5,21; лужногідролітичного азоту (за Корнфільдом) - 16,05 ; рухомих форм фосфору (за Чіріковим) - 17,9; калію (за Чіріковим) - 19,2 мг на 100 г грунту.

Попередник у досліді - горох. Обробіток грунту та догляд за посівами проводили в строки, з урахуванням попередника і грунтово-кліматичних умов. Фосфорно-калійні добрива вносили під передпосівну культивацію у формі гранульованого суперфосфату $\left(\mathrm{P}_{2} \mathrm{O}_{5}-19,5 \%\right)$, калійної солі $\left(\mathrm{K}_{2} \mathrm{O}-40\right)$ і аміачної селітри $(\mathrm{N}-34 \%)$, карбамід $\left(\mathrm{Co}\left(\mathrm{NH}_{2}\right) 21-46,2 \%\right), \mathrm{KAC}$ - розчин аміачної селітри та карбаміду (50 х 50) за схемою, наведеною в таблиці 1. Сіяли тритикале 3 нормою висіву 4,5 млн шт. (229 кг/га) на глибину 3-4 см. Maca 1000 зерен становила 50 грам. Облікова площа - 33 м², повторність досліду - триразова. Агротехніка - загальноприйнята для Полісся. Система захисту рослин включала хімічну боротьбу проти бур'янів навесні. У фазі кущіння посіви обробляли гербіцидом «Граділ-Плюс» (100 г/га).

Фази розвитку відмічали, коли $75 \%$ рослин сягали цього ступеня розвитку. Облік густоти продуктивного стеблостою на облікових ділянках розміром $1 \mathrm{~m}^{2}$ проводили перед збиранням урожаю. Коефіцієнт продуктивного кущіння встановлювали за результатами аналізу пробного снопа, співвідношенням кількості продуктивних стебел і рослин. Збирали врожай комбайном «Дір - Корнік» (KLASS).

Дані обчислювали методом дисперсійного аналізу. Визначення показників структури врожаю проводили 3 пробних снопів, зібраних із двох погонних метрів у двох несуміжних повтореннях, у різних місцях ділянки за методикою Майсуряна. Масу 1000 насінин визначали за методиками ДСТУ, а якісні показники - в лабораторії хімічних масових аналізів Інституту АПВ $[4,8]$.

Результати експериментальних досліджень. Встановлено, що фактори досліду по-різному впливали на ріст і розвиток рослин тритикале озимого. Так, на 1-2-му варіантах продуктивне кущіння характеризується коефіцієнтами 1,0 1,1 , то у варіантах удобрення $\mathrm{N}_{30-60-90-120} \mathrm{P}_{60} \mathrm{~K}_{120}-$ 1,2-1,7 відповідно, що допомогло сформувати рослинам від 503,4 до 715,7 шт./м² продуктивних стебел і забезпечити їх виживання на рівні 97,299,8 \%. Вплив внесення карбаміду на ці показники в усіх варіантах (3-6) був найбільший (табл. 2).

\section{1. Схема досліду}

\begin{tabular}{|c|c|c|}
\hline $\begin{array}{l}\text { № } \\
\text { ח/ח }\end{array}$ & Варіанти досліду & Види добрив \\
\hline 1 & Контроль (без добрив) & - \\
\hline 2 & $\mathrm{P}_{60} \mathrm{~K}_{120}-$ фон у передпосівну культивацію & суперфосфат-хлористий калій \\
\hline 3 & \multirow{3}{*}{ Фон - $\mathrm{N}_{30} 3$ осені в передпосівну культивацію } & карбамід \\
\hline 4 & & аміачна селітра \\
\hline 5 & & KAC \\
\hline 6 & \multirow{3}{*}{ Фон $\mathrm{N}_{60}$, де $\mathrm{N}_{30} 3$ осені $+\mathrm{N}_{30}$ відновлення весняної вегетації } & карбамід \\
\hline 7 & & аміачна селітра \\
\hline 8 & & $\mathrm{KAC}$ \\
\hline 9 & \multirow{3}{*}{$\begin{array}{c}\text { Фон } \mathrm{N}_{90}, \text { де } \mathrm{N}_{30} 3 \text { осені }+\mathrm{N}_{30} \text { відновлення весняної вегетації } \\
+\mathrm{N}_{30} \text { вихід у трубку }\end{array}$} & карбамід \\
\hline 10 & & аміачна селітра \\
\hline 11 & & KAC \\
\hline 12 & \multirow{3}{*}{$\begin{array}{c}\text { Фон } \mathrm{N}_{120} \text {, де } \mathrm{N}_{30} 3 \text { осені }+\mathrm{N}_{30} \text { відновлення весняної вегетації } \\
+\mathrm{N}_{30} \text { вихід у трубку }+\mathrm{N}_{30} \text { прапорцевий листок }\end{array}$} & карбамід \\
\hline 13 & & аміачна селітра \\
\hline 14 & & KAC \\
\hline
\end{tabular}


СІЛЬСЬКЕ ГОСПОДАРСТВО. РОСЛИННИЦТВО

2. Вплив видів, норм і строків внесення мінеральних добрив на показники продуктивності рослин тритикале озимого сорту Поліський 7 (2010-2011 рр.)

\begin{tabular}{|c|c|c|c|c|c|c|c|}
\hline $\begin{array}{l}\text { № } \\
\Pi / \Pi\end{array}$ & Схема досліду & $\begin{array}{c}\text { Види } \\
\text { добрив }\end{array}$ & $\begin{array}{c}\text { Польова } \\
\text { схожість, } \\
\text { \% }\end{array}$ & $\begin{array}{c}\text { Коефі- } \\
\text { цієнт } \\
\text { прод. } \\
\text { кущення }\end{array}$ & $\begin{array}{c}\text { К-сть } \\
\text { продук- } \\
\text { тивних } \\
\text { стебел, } \\
\text { шт./м² }\end{array}$ & $\begin{array}{c}\text { Вижи- } \\
\text { вання, \% }\end{array}$ & $\begin{array}{c}\text { К-сть } \\
\text { рослин до } \\
\text { збирання, } \\
\text { шт./м² }\end{array}$ \\
\hline 1 & Контроль (без добрив) & - & 90,6 & 1,0 & 450,0 & 99,3 & 405,5 \\
\hline 2 & $\mathrm{P}, \mathrm{K}$ & PK & 91,0 & 1,1 & 458,2 & 99,1 & 406,0 \\
\hline 3 & \multirow{3}{*}{$\begin{array}{l}\text { Фон - } \mathrm{N}_{30} 3 \text { осені } \\
\text { під культивацію }\end{array}$} & карбамід & 93,7 & 1,3 & 522,6 & 99,1 & 418,5 \\
\hline 4 & & селітра & 94,4 & 1,2 & 503,4 & 99,2 & 422,0 \\
\hline 5 & & KAC & 95,5 & 1,4 & 547,4 & 98,8 & 425,0 \\
\hline 6 & \multirow{3}{*}{ Фон $+\mathrm{N}_{30} 3$ осені $+\mathrm{N}_{30}$ III } & карбамід & 95,5 & 1,5 & 603,0 & 97,9 & 420,0 \\
\hline 7 & & селітра & 95,6 & 1,5 & 609,0 & 98,8 & 425,0 \\
\hline 8 & & KAC & 95,6 & 1,5 & 618,0 & 98,7 & 425,0 \\
\hline 9 & \multirow{3}{*}{$\begin{array}{c}\text { Фон }+\mathrm{N}_{30} 3 \text { осені }+\mathrm{N}_{30} \text { III } \\
+\mathrm{N}_{30} \mathrm{~V}\end{array}$} & карбамід & 94,6 & 1,6 & 661,6 & 98,1 & 418,0 \\
\hline 10 & & селітра & 95,7 & 1,5 & 608,2 & 98,1 & 423,5 \\
\hline 11 & & KAC & 95,4 & 1,6 & 636,0 & 98,6 & 423,5 \\
\hline 12 & \multirow{3}{*}{$\begin{array}{c}\text { Фон }+\mathrm{N}_{30} \text { з осені }+\mathrm{N}_{30} \text { III } \\
\quad+\mathrm{N}_{30} \mathrm{~V}+\mathrm{N}_{30} \mathrm{VII}\end{array}$} & карбамід & 95,4 & 1,7 & 715,7 & 98,3 & 422,5 \\
\hline 13 & & селітра & 95,5 & 1,6 & 665,6 & 98,2 & 422,5 \\
\hline 14 & & KAC & 97,1 & 1,7 & 722,5 & 96,2 & 420,5 \\
\hline
\end{tabular}

3. Вилив норм і строків внесення різних видів мінеральних добрив на врожай $і$ якість зерна озимого тритикале сорту Поліський 7 (2010-1011р.)

\begin{tabular}{|c|c|c|c|c|c|c|c|c|c|c|c|}
\hline \multirow[b]{2}{*}{$\begin{array}{l}\text { № } \\
\Pi / \Pi\end{array}$} & \multirow[b]{2}{*}{ Схема досліду } & \multirow[b]{2}{*}{$\begin{array}{l}\text { Види } \\
\text { добрив }\end{array}$} & \multicolumn{3}{|c|}{ Врожайність } & \multicolumn{6}{|c|}{ Вміст, \% } \\
\hline & & & т/га & $\begin{array}{l} \pm \text { до } \\
\text { конт- } \\
\text { ролю }\end{array}$ & $\begin{array}{l} \pm \text { до } \\
\text { фону }\end{array}$ & Білок & $\begin{array}{c}\text { Клей- } \\
\text { кови- } \\
\text { на }\end{array}$ & $\begin{array}{l}\text { Крох- } \\
\text { маль }\end{array}$ & Зола & $\mathrm{P}_{2} \mathrm{O}$ & $\mathrm{K}_{2} \mathrm{O}$ \\
\hline 1 & $\begin{array}{c}\text { Контроль } \\
\text { (без добрив) }\end{array}$ & - & 3,58 & - & - & 10,1 & 15,0 & 62,06 & 1,89 & 0,88 & 0,63 \\
\hline 2 & $\mathrm{P}_{60} \mathrm{~K}_{120}-\phi о \mathrm{\phi O}$ & PK & 4,46 & - & - & 11,1 & 15,8 & 62,23 & 2,01 & 0,93 & 0,70 \\
\hline \multirow{3}{*}{$\begin{array}{l}3 \\
4 \\
5\end{array}$} & \multirow{3}{*}{$\begin{array}{c}\text { Фон }+ \\
\mathrm{N}_{30} 3 \text { осені під } \\
\text { культивацію }\end{array}$} & сечовина & 5,12 & 1,54 & 0,65 & 11,8 & 18,1 & 60,83 & 2,1 & 0,94 & 0,71 \\
\hline & & селітра & 5,13 & 1,55 & 0,66 & 12,3 & 20,4 & 61,52 & 2,0 & 0,91 & 0,67 \\
\hline & & KAC & 5,35 & 1,8 & 0,92 & 13,1 & 21,9 & 59,8 & 1,69 & 0,89 & 0,65 \\
\hline \multirow{3}{*}{$\begin{array}{l}6 \\
7 \\
8\end{array}$} & \multirow{3}{*}{$\begin{array}{c}\text { Фон }+ \\
\mathrm{N}_{30} 3 \text { осені }+ \\
\mathrm{N}_{30} \text { III етап }\end{array}$} & сечовина & 5,72 & 2,14 & 1,26 & 12,7 & 20,6 & 59,87 & 1,87 & 0,95 & 0,68 \\
\hline & & селітра & 5,44 & 1,86 & 0,98 & 11,7 & 21,2 & 59,25 & 2,17 & 0,94 & 0,71 \\
\hline & & KAC & 5,5 & 1,92 & 1,04 & 14,1 & 21,2 & 58,64 & 2,03 & 0,98 & 0,73 \\
\hline \multirow{3}{*}{$\begin{array}{c}9 \\
10 \\
11\end{array}$} & \multirow{3}{*}{$\begin{array}{c}\text { Фон }+ \\
\mathrm{N}_{30} 3 \text { осені }+ \\
\mathrm{N}_{30} \text { III етап }+ \\
\mathrm{N}_{30} \text { V етап }\end{array}$} & сечовина & 5,62 & 2,04 & 1,16 & 12,2 & 21,0 & 59,32 & 2,11 & 1,00 & 0,73 \\
\hline & & селітра & 5,66 & 2,08 & 1,19 & 12,5 & 21,2 & 59,96 & 2,2 & 0,94 & 0,67 \\
\hline & & KAC & 5,75 & 2,17 & 1,29 & 13,8 & 21,0 & 60,87 & 2,02 & 0,91 & 0,73 \\
\hline \multirow{3}{*}{$\begin{array}{l}12 \\
13 \\
14\end{array}$} & \multirow{3}{*}{$\begin{array}{c}\text { Фон }+ \\
\mathrm{N}_{30} 3 \text { осені }+ \\
\mathrm{N}_{30} \text { III етап }+ \\
\mathrm{N}_{30} \text { V етап }+ \\
\mathrm{N}_{30} \text { VII етап }\end{array}$} & сечовина & 5,98 & 2,4 & 1,52 & 14,1 & 21,0 & 62,68 & 2,19 & 0,91 & 0,70 \\
\hline & & селітра & 5,59 & 2,01 & 1,48 & 13,3 & 19,9 & 60,62 & 1,93 & 0,91 & 0,68 \\
\hline & & KAC & 5,88 & 2,3 & 1,65 & 14,2 & 21,1 & 60,15 & 2,02 & 0,90 & 0,63 \\
\hline
\end{tabular}

Примітка: $\mathrm{HIP}_{05}-3,15$ u̧/2a

Максимальне збільшення врожаю зерна тритикале озимого досягнуто від застосування повних мінеральних добрив, особливо азотних. Якщо у варіанті, де його не застосовували (варіанти 1,2 ), урожайність становила $35,8-44,6$ ц/га,

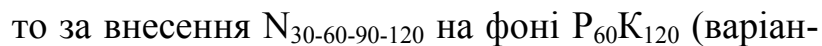
ти $3,4,5,6)$ вона була на рівні $51,2-59,8$ ц/га. Урожайність від внесення азоту зросла, відповідно, на 15,4-24,0 ц/га. Найбільшою вона була за використання $\mathrm{KAC}(18,0-23,0$ ц/га). 
Це свідчить про те, що застосування карбаміду і КАС по етапах органогенезу $\mathrm{N}_{30}$ III $+\mathrm{N}_{60}$ III, $\mathrm{N}_{90}$ III-V, $\mathrm{N}_{120}$ III-V i VII етап, можна впливати на регулювання цього показника, отримати значно більшу врожайність (табл. 3). Застосування сечовини на 4-6-му варіантах сприяло формуванню врожайності зерна на рівні 57,5-65,2 ц/га. Одним із основних показників якості зерна $\epsilon$ вміст у ньому білка, клейковини та крохмалю, на які певний вплив мають як норми, дози і строки внесення азотних добрив, так і їх співвідношення, внесені за етапами органогенезу. Проведені дослідження стали підтвердженням цього. Так, найбільше формувалося білка в зерні тритикале на фонах $\mathrm{N}_{60} \mathrm{P}_{60} \mathrm{~K}_{120}, \mathrm{~N}_{90} \mathrm{P}_{60} \mathrm{~K}_{120}, \mathrm{~N}_{120} \mathrm{P}_{60} \mathrm{~K}_{120}$ на 4-6-му варіантах, відповідно, 12,7-14,2 \%, особливо за внесення добрив у формі суміші селітри й карбаміду (КАС) на рівні 13,1-14,2 \%. Адекватно змінювався і показник клейковини. Так, за внесення карбаміду, селітри і КАС (варіанти 36) восени і на III, V i VII етапах органогенезу він становив 18,1-21,1\%, що на 3,1-6,1 \% більше контрольного варіанту і фосфорного калійного фону.

До того ж показник крохмалю має тенденцію до зростання на 3-6-му варіантах, де застосовувалася селітра, сечовина і КАС, відповідно,

\section{БІБЛІОГРАФІЯ}

1. Білітюк А. П. Ріст і розвиток рослин тритикале залежно від впливу мінеральних добрив / Білітюк А. П. // Вісник аграрної науки. - 2002. № 8. - C. 23-27.

2. Білітюк А. П. Біологічні особливості вирощування озимого тритикале / Білітюк А. П., Каленська С. М. // Вісник аграрної науки. - 2004. № 3. - C. 20-26.

3. Білітюк А. П. Тритикале в Україні / [Білітюк А. П., Гірко В. С., Каленська С. М., Андрушків М. І.] // За ред. А. П. Білітюка. - К., 2004. - 376 с.

4. Доспехов Б. А. Методика полевого опыта (С основами статистической обработки результатов исследований) / Б. А. Доспехов. - М. : Агропромиздат, $1985 .-351 \mathrm{c}$.

5. Каленська С. М. Тритикале - нові сорти, нові перспективи / С. М. Каленська, С. Б. Янішевський // Агроінком. - 1998. - № 3-4. - С. 21-22.

6. Каленська С. М. Продуктивність озимого тритикале залежно від технологій вирощування / С. М. Каленська, Г. В. Кононюк // Землеробство.
60,15-62,68 \% при показнику на контролі, фосфорно-калійному фоні - 62,06-62,23\%. Відповідно нормам, формам і строкам внесення мінеральних добрив (сухих і водорозчинних) параметри вмісту в зерні золи, фосфору і калію практично змінювалися на одному рівні - від 1,72-2,19; 0,88-1,00; 0,63-0,73 \% відповідно. Дещо меншими були ці показники при застосуванні водорозчинних добрив, які вочевидь сприяли кращому використанню рослинами їх у ході веснянолітньої вегетації.

Висновки. На дерново-підзолистому супіщаному грунті Західного Полісся України по попереднику горох оптимальною дозою мінеральних добрив для тритикале озимого сорту Поліський 7 $\epsilon \mathrm{N}_{120} \mathrm{P}_{60} \mathrm{~K}_{120}$, внесених $\mathrm{N}_{30}$ до сівби $+\mathrm{N}_{30} \mathrm{III}+\mathrm{N}_{30}$ $\mathrm{V}+\mathrm{N}_{30} \mathrm{VII}$ етапах органогенезу у формі карбоміду і КАС. На цьому агрофоні врожайність зерна становила 59,8-58,8 ц/га із вмістом 14,1-14,2 \% білка i 21,1 \%, клейковини відповідно. Дещо нижчі показники отримали при застосуванні аміачної селітри. Відповідно до форм і норм внесених мінеральних добрив змінювалися параметри вмісту в зерні крохмалю, золи, фосфору і калію, зростала довжина стебла й колоса прапорцевого листка, кількість колосків у колосі, зерен у ньому.

- 1996. - Вип. 71. - С. 78-81.

7. Каленська С. М. Агроекологічні аспекти застосування добрив в технологіях вирощування тритікале / С. М. Каленська // Зб. наук. пр. I3 УААН. - К., 1997. - C. 187-189.

8. Насіння сільськогосподарських культур. Сортові та посівні якості. Технічні умови : ДСТУ 4138-2002. - К. : Держстандарт України, 2002. 74 с. - (Національний стандарт України).

9. Особенности азотного питания озимого тритикале / Гриб С. И., Кукрин Н. П., Булавина Т. М. [и др.] // Земледелие. - 1999. - № 1. C. 29.

10. Рябчун B. K. Хлебопекарное качество зерна новых линий яровых гексаплоидных тритикале / В. К. Рябчун, В. И. Шатохин, И. А. Панченко // Тези Міжнар. конф. «Наукові основи стабілізації виробництва продукції рослинництва». Інститут рослинництва ім. В. Я. Юр'єва. - Х., 1999. - C. 199-200. 